\title{
Ramona Thieme Mercer'ın Annelik Rolü Yeteneği ve Anne Olma Kuramını Anlamak: Planlanmamış Adölesan Gebelik Örneği
}

\author{
Understanding Ramona Thieme Mercer's Maternal Role Attainment and Becoming a Mother: Unplanned \\ Adolescent Pregnancy Sample
}

Bahar ÇOLAK ${ }^{1}$, Birsel Canan DEMİRBAĞ², $\breve{I ̇ l k n u r ~ K A H R I M A N ~}^{3}$

\begin{abstract}
ÖZ
Bebeğin aileye katılması, aile üyelerine yeni sorumluluklar yüklemektedir. Özellikle kadın için anne olmak, birçok zorlukları beraberinde getirmektedir. Annelik rolü yeteneğinin kazanılmasında sadece kadının değil, tüm aile bireylerinin üstlerine düşen görevler bulunmaktadır. Sağlıklı bir doğum sürecinin yaşanması ya da sağlıklı bir bebeğin doğumu ile tüm aile bireylerinin hayatı etkilenirken komplikasyonlu gebelikler, engelli çocuğa sahip olma, ilk doğum deneyimi, planlanmamış gebelikler ve adölesan gebelikler gibi özel durumlarda ise gebeliğe hazırlanmak ya da doğan bebeğe adapte olmak daha zor olmaktadır.

Annelik rolü yeteneği ve anne olma kuramında; anneye ve tüm aile bireylerine doğuma hazırlık, eğitim ve danışmanlıkların yapılması gerektiği yer almaktadır. Tüm bu süreçler ile anne adayı, anneliğe hazırlanmaktadır. Kuram, doğum öncesi ve doğum sonrası zamanları kapsadığı için ayrıntılı bir değerlendirme gerektirmektedir. $\mathrm{Bu}$ çalışmada planlanmamış gebeliği olan adölesan bir annenin, annelik rolü yeteneği ve anne olma kuramı ile anneliğe adaptasyonu incelenerek; hemşirelere yol göstermesi, mesleğe bilimsel bilimsel katkı sağlaması ve kuramın değerlendirlmesi amaçlanmıştır. İlk olarak kuramlar ile ilgili bilgi verilmiş, daha sonra vaka örneği sunulmuştur. Sonuç olarak kuramın uzun bir süreyi kapsamasından dolayı zaman yetersizlikleri olabileceği zayıf yönü olarak görülürken tüm aile ile hemşirenin iletişime geçerek uzun bir süre danışmanlık yapması da kuramın güçlü yönü olarak görülmüştür.
\end{abstract}

Anahtar Kelimeler: Anneler, Anne-Bebek İlişkisi, Adölesan Gebelik.

\begin{abstract}
Joining a baby into the family puts new responsibilities on the family members. Becoming a mother especially for women brings with it many difficulties. In maternal role attainment not only women but also all family members have their duties. While having a healthy birth process or the birth of a healthy baby is affected by the life of all family members, it is more difficult to prepare for pregnancy or adapt to the born baby in special cases such as complicated pregnancies, having a disabled child, first birth experience, unplanned pregnancies and adolescent pregnancies.
\end{abstract}

Necessary preparation, education and counseling should be provided to the mother and all family members in the maternal role attainment and becoming a mother theory. With all these processes, the expectant mother is preparing for motherhood. The theory requires a detailed evaluation as it covers pre-natal and postnatal times. In this study, the motherhood role ability of an adolescent mother with unplanned pregnancy was examined and her adaptation to motherhood with her theory of being a mother; It is aimed to guide nurses, provide scientific scientific contribution to the profession, and evaluate the theory. Firstly, information was given about the theories and then a sample case was presented. Consequently, it was seen as the weakness that time deficiencies might be due to the theory's long-term coverage, while the consultation of the whole family and the nurse for a long time was also seen as the strength of the theory.

Keywords: Mothers, Mother-Infant Relations, Adolescent Pregnancy.

\footnotetext{
${ }^{1}$ Arş. Gör. Bahar ÇOLAK, Çocuk Sağlı̆̆ı ve Hastalıkları Hemşireliği, Karadeniz Teknik Üniversitesi, Sağlık Bilimleri Fakültesi, b.colak9367@gmail.com, ORCID: 0000-0002-0850-9114

2 Prof. Dr. Birsel Canan DEMİRAĞ, Halk Sağlı̆̆ı Hemşireliği, Karadeniz Teknik Üniversitesi, Sağlık Bilimleri Fakültesi, bc.demirbag@ktu.edu.tr, ORCID: 0000-0002-7533-7201

3 Doç. Dr. İlknur KAHRİMAN, Çocuk Sağlığı ve Hastalıkları Hemşireliği, Karadeniz Teknik Üniversitesi, Sağlık Bilimleri Fakültesi, ilknurkahriman@ktu.edu.tr, ORCID: 0000-0002-6968-9446
} 


\section{GIRISS}

Adölesan gebelikler; anne, çocuğu ve ailesi için önemli sağlık sorunları, duygusal ve sosyal sonuçları olan ülkemizdeki yaygın bir halk sağlığı sorunudur. 2013'den bu yana adölesan gebeliklerde (15-19 yaş) \%5'den \%4'lere düşüş yaşansa da hâla önemli bir sorun olarak karşımıza çıkmaktadır. TNSA 2018' e göre adölesan dönemdeki kadınların (15-19 yaş) \%3,5'i çocuk sahibi olmaya başlamıştır. ${ }^{1}$ Adölesan anne adaylarının kaygısı, yetişkin annelere göre daha yüksek olmakla birlikte daha fazla danışmanlık ve yardıma ihtiyaçları bulunmaktadır. Adölesan anneler doğum komplikasyonlarına da daha eğilimli olmaktadır, erken ve düşük doğum ağırlıklı ya da anomalili bebekleri olabilmektedir. Bunların yanında annenin deneyimsiz oluşu başta emzirmenin gerçekleştirilememesi olmak üzere diğer bakımların da yerine getirilememesine neden olmaktadır. Ayrıca tüm bunlar anne ile bebeğin bağlanmasını olumsuz yönde etkileyebilmektedir. ${ }^{2-4}$ Çınar ve arkadaşlarının (2019) araştırmasında adölesan annelerin; anneliğe yeterince hazır olmadıkları ve ilk emzirme deneyimlerinde daha fazla desteğe gereksinim duydukları belirlenmiştir. Annelere gereksinimleri doğrultusunda gerekli eğitim ve desteğin verilmesi gerektiği önerilmiştir. $^{2} \mathrm{Bu}$ doğrultuda bu çalışma; ülkemiz için hâla önemli bir sorun olan adölesan anneleri gebeliğe hazırlamak, danışmanlık yapmak ve eğitimlerin verilmesini sağlamak (bebek bakımı, gebeliğe hazırlık vb.), yalnızca adölesan anneyi değil tüm aile bireylerine gerekli desteği sunmak ve gerekli girişimleri yapmak için planlanmıştır. Çalışma; Mercer'ın geliştirdiği annelik rol yeteneği ve anne olma kuramının kullanılarak, kanıt temelli yaklaşım sunulması, klinik, toplum sağlığ1 merkezleri ve aile sağlığ merkezlerinde hemşirelik kuramlarının kullanılmasının sağlanması açısından önem taşımaktadır. Çalışmamızda ilk olarak annelik rolü yeteneği ve anne olma kuramı ayrıntılı olarak açıklanmış sonrasında ise bir vaka örneği ile kuram pekiştirilmeye çalışılmıştır. Çalışmanın ana hedefi annelik rolü yeteneği ve anne olma kuramının hemşireler tarafından anlaşılmasını sağlamaktır. Ayrıca hemşirelik mesleğimizde bilimsel dayanağımız olan hemşirelikte kuram literatürümüzün güçlendirilmesi ve katkıda bulunulması çalışmanın hedefleri arasındadır.

\section{Ramona Thieme Mercer}

Ramona Thieme Mercer, 4 Ekim 1929'da Alabama, Amerika Birleşik Devletleri'nde dünyaya gelmiştir. William Henry ve Nell Thieme'nin kızıdır. Karayipler'de bir gezide mühendis ve tesis müdürü olan Lewis Mercer ile tanışmış ve 31 Aralık 1971'de evlenmiştir. Camillie E. Ronay adında bir kızları bulunmaktadır., 6

Mercer, 1950'de hemşirelik diplomasını Montgomery, Alabama'daki St. Margaret's Hemşirelik Okulu'ndan alarak hemşirelik mesleğine başlamıştır. Bu okuldan en yüksek akademik derece ile mezun olarak L.L. Hill Ödülünü almıştır. Servis hemşiresi ve başhemşire olarak çalıştıktan sonra henüz lisansını yapmadan önce üstün başarılarından dolayı 1960'da pediatri, obstetri ve bulaşıc1 hastalıklar dallarında okulda eğitimci olmuştur. Lisansını 1962'de New Mexico Üniversitesi'nde tamamlamıştır. Mercer, hemşirelikte çalışmalarına devam ederken, Emory Üniversitesinde "kamu sağllğ1 hizmetleri bölümü staj ödülü”nü almıştır. 1964'te ise bu üniversitede anne çocuk hemşireliği alanında yüksek lisansını yapmıştır. On yıl boyunca sorumlu hemşire, başhemşire ve eğitmen olarak meslek hayatına devam etmiştir. 1973'de ise Pittsburgh Üniversitesi'nde anne sağlığ1 hemşireliği alanında doktorasını tamamlamıştır. Doktorayı tamamladıktan sonra California'ya taşınmış ve California Üniversitesi'nde aile sağlığg hemşireliği bölümünde asistanlığa başlamıştır. 1977 yılında doçentliğini ve 1983 y1lında ise profesörlük ünvanını almıştır. 1987 yılında emekli olan Mercer, California Üniversitesi'nde aile sağlı ̆̆ hemşireliğginde hâla fahri profesördür. 2003 yılında California, Carlsbad'da gerçekleştirilen Amerikan Hemşirelik Akademisinin yıllık toplantısında Mercer'e "yaşayan efsane" 
ünvanı verilmiștir. 2004'de ise New Mexico Üniversitesi Mercer'1 ilk defa verilen "hemşirelik koleji seçkin mezun ödülü" ile onurlandırmıştır. Ayrıca ismi San Francisco California üniversitesinin onur panosunda yer almaktadır. Mercer'ın birçok makale, kitap ve kitap bölümleri bulunmaktadır.,

\section{Mercer'ın Kuramını Geliştirme Süreci}

Mercer, kuramını geliştirirken tümden gelim ve tüme varım yöntemlerinden yararlanmıştır. Tümden gelim yönteminde başka araştırmacılar ve onların teorilerinden yararlanırken, tüme varım yönteminde ise kendi yapmış olduğu uygulama, araștırma ve gözlem sonuçlarından faydalanmıștır. Mercer; annelerin, annelik rolü yeteneklerini araştırırken özellikle doğum sonrası komplikasyonu olan, engelli çocuğa sahip olan ve adölesan yaşta ebeveyn olan annelerin anneliğe uyumlarında farklılık olduğunu gözlemlemiştir. ${ }^{6}$

Mercer, doktorasını yaptığı Pittsburgh Üniversitesi'nde danışmanı olan Profesör Reva Rubin'den etkilenmiş ve kuramını geliștirirken ilk desteği de bu hocasından almıştır. Rubin'in annelik rolünü anlamayı ve annelik rolü kazanımını tanımlamasını içeren araştırmaları uzun yıllar obstetri alanında hemşireler için temel bir teori olarak kullanılmıştır. Rubin'in anne rolü kazanımını etkilediğini öne sürdüğü faktörler ile ilgili kavramlar ve düşünceleri Mercer'in araştırmasının yapı taşlarını oluşturmuştur. ${ }^{8-11}$

Mercer kuramının çerçevesini oluștururken yararlandığı önemli bir diğer bilim insanı ise, Rus kökenli Amerikalı bir gelişim psikoloğu olan Urie Bronfenbrenner 'dir. Mercer, Brofenbrenner'in ekolojik sistem teorisini annelik rol yeteneği ve anne olma kuramlarına entegre etmiştir. ${ }^{12}$

Bronfenbrenner, ekolojik sistem modeli üzerinde 1970'li yıllarda çalışmaya başlamıştır ve 1980 de ise teorik bir model haline getirmiştir. Teori, biyo-ekolojik model olarak da adlandırılmakta ve insan gelişimini açıklamaktadır. Brofenbrenner, bir çocuğun sağlıklı bir şekilde gelişerek topluma kazandırılmasını meyvelerin olgunlaşmasına benzer şekilde ele almaktadır. Çocuğun gelişiminin, çocuğu merkeze yerleştiren ve birbirini katman katman saran sistemler şeklinde tanımlanan bir çevre içinde gerçekleștiğini belirtmektedir (Şekil 1). Herhangi bir sistemde meydana gelen olay ve durumlar diğer sistemleri de etkilediği gibi birbiriyle karşılıklı dinamik bir etkileşim içinde olan bu sistemler çocuğun gelişimini de etkilemektedir. Aynı zamanda çocuğun davranışları çevresindeki bireylerden ve ilişkilerden etkilendiği gibi, çocuk da onları etkilemektedir. Çocuğun sağlıklı gelișimi için sistemler arasındaki etkileșimin tutarlı olması önem taşımaktadır. Bu sistemler arasında hiyerarşik bir yapı bulanmaktadır. Hiyerarşideki her seviye bir yükselmeye işaret etmektedir. Sirasıyla birbirini saran bu sistemler içten dışa doğru; mikrosistem, mezosistem, ekzosistem, makrosistem ve kronosistem şeklinde isimlendirilmektedir. ${ }^{13-}$ 14

Mikrosistem; bu sistem çocuğa en yakın olan ve çocuğu ilk saran sistemdir. Çocuğun aile, okul ve arkadaş gibi en yakınında olan kişilerin yer aldığ 1 sistemdir. Çocuğun gelişimi üzerindeki en büyük etkiye sahiptir. Çocuğun gelişiminin temel yapısı burada şekillenmektedir. Burada yaşanan büyük sıkıntılar çocuk üzerinde oldukça yıkıcı etkiler yaratmaktadır. ${ }^{13}$

Mezosistem; mikrosistemi saran sistemdir. Çocuğun etkileșim içinde olduğu iki veya üzerinde mikrosistem elemanının arasındaki ilişkiyi içermektedir. "Aile ve arkadaşlar", "aile ve öğretmenler", "aile ve okul yönetimi", "öğretmenler ve okul yönetimi" gibi etkileşimler burada yer almaktadır. Bu sistem de çocuğun gelişimi üzerinde büyük etkiye sahiptir. ${ }^{15}$

Ekzosistem; mezosistemi saran sistemdir. $\mathrm{Bu}$ sistem, çocuğun primer olarak içinde olmadığı ancak dolaylı olarak çocuğun gelişimini etkileyen etkileşimlerdir. "Okulaile birliklerinin" ve "il ve ilçe milli eğitim müdürlüklerininilişkileri” ve "anne-babanın işyerindekiilişkileri” bu sistemde yer almaktadir. ${ }^{13}$

Makrosistem; ekzosistemi çevreleyen sistemdir. Çocuğun içinde yaşadığı topluma ait özelliklerin etkileşimini içerir. Toplumun kültürü, gelenekleri, değerleri, inancı, yaşam 
stilleri, kanunlar, sağlık bu sistemin önemli öğeleridir. ${ }^{13}$

Kronosistem; Bronfenbrenner modeline en son bu sistemi eklemiştir. "kronosistem" en geniş sistemdir. $\mathrm{Bu}$ sistem insanın hayatı boyunca tutarlılık gösteren ya da değişebilen faktörlerini içerir. Zamanla değişen koşulların insan üzerindeki yansımalarını kapsamaktadır. Anne babanın boşanması, ekonomik zorluklar, göç ve savaşlar gibi öğeler bu sistemde yer almaktadır. Bu gibi değişimler çocuğun sosyal etkileşimlerini değiştirir. Çocuğun sosyal etkileşiminin yapısı farklılaştıkça çocuğu saran sistemlerin konumu da değișmektedir. ${ }^{16-17}$

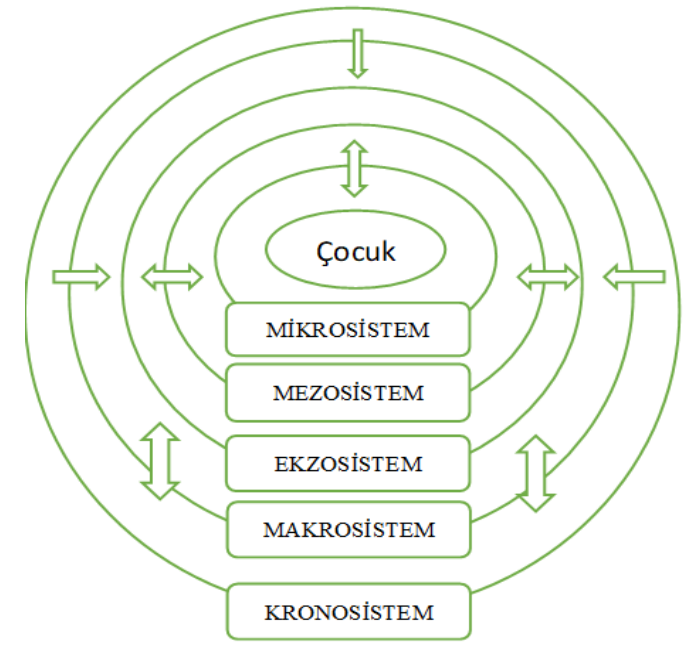

Şekil 1. Ekolojik Sistem Modelii ${ }^{13-14}$

\section{Mercer'in Orijinal Anne Rolü Kazanım Teorisine (Rubin'in teorisi) Genel Bakışı}

Annelik rolüne ulaşma ve annelik kimliği kavramları ilk olarak 1967 yılında Reva Rubin tarafından ele alınmıştır. Mercer, danışmanı olan Rubin'den etkilenerek bu konu üzerinde araştırmalar yapmaya başlamıştır. ${ }^{18}$ Rubin annelik rolünü doğumdan önce ve doğumdan sonraki ilk bir ay içinde incelemiştir ve yalnızca sağlıklı anneler ile çalışmıştır. Ayrıca annelik rolünün kazanılmasında babanın etkisi üzerinde durmamıştır. Mercer ise hocasının ortaya koyduğu bu kavramlara eklemeler yapmıştır. Annelik rolü kazanımını doğumdan sonraki ilk bir yıla kadar uzatarak incelemiştir. Sadece sağlıklı anneleri değil yüksek riskli gebeliği olan, engelli bebeği olan, adölesan yaşta olan risk gruplu anneleri teoriye dâhil etmiş ve ilk çalışmalarını da bu gruplarda yapmıştır. Ayrıca annelik rol kazanımının üzerinde babanın önemini ve etkisini de ele almış ve bu kavramları özellikle vurgulamıştır. ${ }^{19} 1981$ y1lında Mercer, annelik rolünü etkileyen unsurları açıklamak için teorik bir çerçeve sunmuş ve 1986 yllında yazdığ $\breve{1}_{1}$ kitapta ise net bir şekilde bu kavramları tanımlamıştır. ${ }^{20}$ Mercer, annelik rolü kazanılmasında birçok faktörün etkili olduğunu belirtmiş ve hocasının kavramlarını geliştirerek anneye ait, aileye ait ve çocuğa ait faktörler olarak üç grupta ele almıştır; ${ }^{1,22}$ Anneye ait faktörler; anne kimliği, doğum deneyimi, benlik saygısı, benlik kavramı, çocuk yetiştirme tutumu, esneklik, annelik rolü becerisi, sağlık durumu, anksiyete, depresyon, rol çatışması, mutlulukmemnuniyet, bağlılıktır. Aileye ait faktörler; ailenin işlevi, baba veya partner, stres, sosyal destektir. Çocuğa ait faktörler; çocuğun sağlığı, çocuk mizac1, çocuğun gönderdiği işaretlerdir.

Mercer annelik rolü kazanımı teorisini 1991 yılında, Amerikan Hemşireler Derneği Hemşire Araştırmacılar Konseyi iş birliği ile düzenlenen "Uluslararası Araştırma Konferansı"nda sunmuştur. Kuramın teorik çerçevesini ise 1995 yılında yazdığı kitabında açıklamıştır. ${ }^{6,23}$

Mercer, annelik rolünün kazanılmasını Thorton ve Nardi'den (1975) uyarlayarak dört aşamada ele almıştır. Sırasıyla bu aşamalar; "Beklentiler Safhası", "Formal (resmi) Safha", "İnformal Safha" ve "Kişisel Safha" dır. ${ }^{10}$

Beklentiler Evresi: $\mathrm{Bu}$ evre gebelikle başlar ve tüm doğum öncesi dönemi kapsar. Kadının annelik rolünü başarabilmesi için ilk olarak gebeliği kabul etmesi ve gebeliği yaşam stiline entegre etmesi gereklidir. $\mathrm{Bu}$ dönem kadının anne adayı olarak tüm yönleriyle gebeliğe hazırlanmasını içermektedir. Öncelikle anne adayının gebeliği kabul durumu ve ön yargıları değerlendirilmelidir. Sonrasında kadının annelik rolünü tanımlayabilmesi ve karnındaki bebeği ile ilişki kurabilmesi sağlanmalıdır. Ayrıca bebek doğmadan önce eş ve çevre ilişkilerinin yeniden düzenlenmesi, sosyal destek kaynaklarının belirlenmesi, doğum için gerekli hazırlıkların yapılmas1 gerekmektedir. $6,8-10,24$ 
Formal (Resmi) Evre: Annenin çocuğunu dünyaya getirmesi ile başlar. $\mathrm{Bu}$ aşamada annenin bebeğinin bakımını yapabilmesi önem taşır. Anne bebeğinin bakımını yaparken hemşiresi tarafından kendisine öğretilen bakım becerilerini tamamen aynı şekilde yapmaya çalışır. ${ }^{10}$ Anne, tamamen rol modellerini taklit eder, çevrenin beklediği gibi davranır. Bu evrede anne bebeğinin bakımını yapabildikçe mutluluk ve memnuniyet sağlayarak annelik rol yeteneği kazanımını ilerletmeye başlar. Annenin doğumu gerçekleştirdikten sonraki iyileşme süreci sağlıklı bir şekilde gerçekleşirse bu rol kazanımı daha kolay gerçekleşecektir. Ancak bu evrede bebeğin bakımı kadar annenin kendi bakımını da sağlıklı bir şekilde yapması gerekmektedir. ${ }^{10,24-26}$

İnformal (Resmi Olmayan) Evre: Anne, bir önceki safha olan formal evrede kendisine öğretildiği gibi aynı şekilde bebeğine bakım verirken bu evrede artık kendi annelik ve bakım stillerini oluşturmaya ve kendi tercihlerini yansıtmaya başlamıştır. $\mathrm{Bu}$ safhada kadın nasıl bir anne olacağını da belirlemeye çalışır. Annelik deneyimi kazandıkça bebeğin bakımında daha esnek davranmaya ve daha ince ayrıntıları fark etmeye başlar. Bu aşamayı sağlıklı bir şekilde geçirdiğinin önemli göstergelerinden biri annelik rollerini yerine getirirken ayn zamanda eş olma gibi diğer rollerini de sağlıklı bir şekilde yerine getirmesi ve rol çatışması yaşamamasıdır. ${ }^{10,24-26}$

Kişisel Evre: Önceki safhaları sağlıklı şekilde yerine getirip kişisel evre aşamasına ulaşan anne, artık anne olmanın keyfini çıkarır. Önceki safhalarda bebek bakımını öğrenmiş, kendi stillerini geliştirmiş, rol çatışması sorununu halletmiş, esnek tutum davranışları geliştirmiş, bebeği ile zevkli zamanlar geliştirmeye başlamış ve anneliğe tamamen uyum sağlamıştır. Bebeğin aileye katılması ile bozulan uyum tekrardan bu evrede sağlanmıştır. Bu evre kısaca annenin rolü kazanmasında ustalaştığ güven kazandığı aşama olarak açıklanabilir. Sonuç olarak bu evrede annelik rolü kazanılmıştır ve kazanılan bu rol, yaşamın sonuna kadar devam eder. ${ }^{10,24-26}$
Mercer, annelik rolü kazanımı kuramını geliştirirken, babanın önemini vurgulamıştır. Babanın desteği, başka herhangi bir kişi tarafından kopyalanamayacak şekilde rol edinme sürecine katkıda bulunur. Babanın etkileşimleri gerginliği dağıtmaya ve anne rol kimliğini kolaylaştırmaya yardımcı olur. Anne, baba ve bebek arasındaki etkileşimleri Şekil 2'deki gibi belirtilmiştir. Anne rol kazanımı ve bebek gelişimi tabakalar ile temsil edilmektedir. Bu doğrultuda anne ve bebeği çevreleyen katmanlar bulunmaktadır. ${ }^{11}$

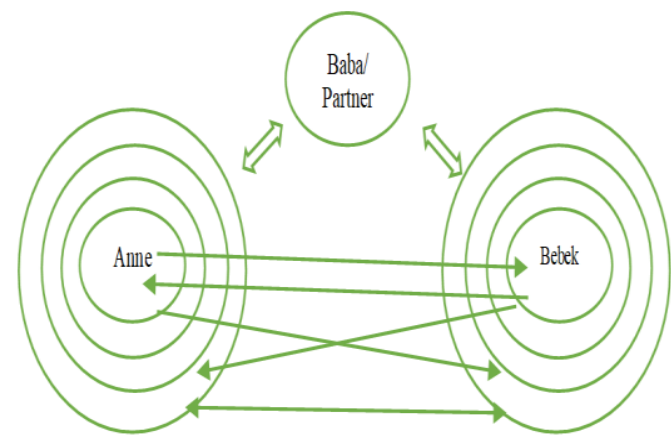

Şekil 2. Anne, Baba ve Bebek Etkileşimi ${ }^{11}$

Mercer; baba, anne ve bebek arasındaki etkileşimleri gösterdikten sonra kuramını açıklarken Brofenbrenner' in ekolojik sistem teorisindeki gibi birbirini kapsayan mikrosistem, ekosistem ve makrosistemi kullanmıştır (Şekil 3). Ekolojik sistem modelinde çocuğa en yakın olan ve çocuğu en çok etkileyen sistem mikrosistem olarak açıklanmıştır. Benzer şekilde Mercer da kuramında mikrosistemi annenin anne rolüne erişmesinde en etkili olan sistem olarak tanımlamıştır. Bu sistem anne, baba, bebek ve aile gibi yakın ilişkileri içerir. Annelik rolü kazanımı ve baba-anne-bebek etkileşimi bu sistemde elde edilir. Ayrica bu sistem aile işlevi, anne-baba ilişkisi, sosyal destek, ekonomik durum, aile gelir ve stresörler gibi öğeleri de içermektedir. Ekosistem; mikrosistemi kapsar ve etkiler. Bu sistem çevreyi içermektedir. İklim, günlük bakım, okul iş düzeni, ibadet gibi kavramlar yer almaktadır. Makrosistem ise; içinde yaşanılan toplumun kültür ve değerleri, sosyo-politik etkilerle mikro ve eko sistemi etkilemektedir. ${ }^{8,9}$ 


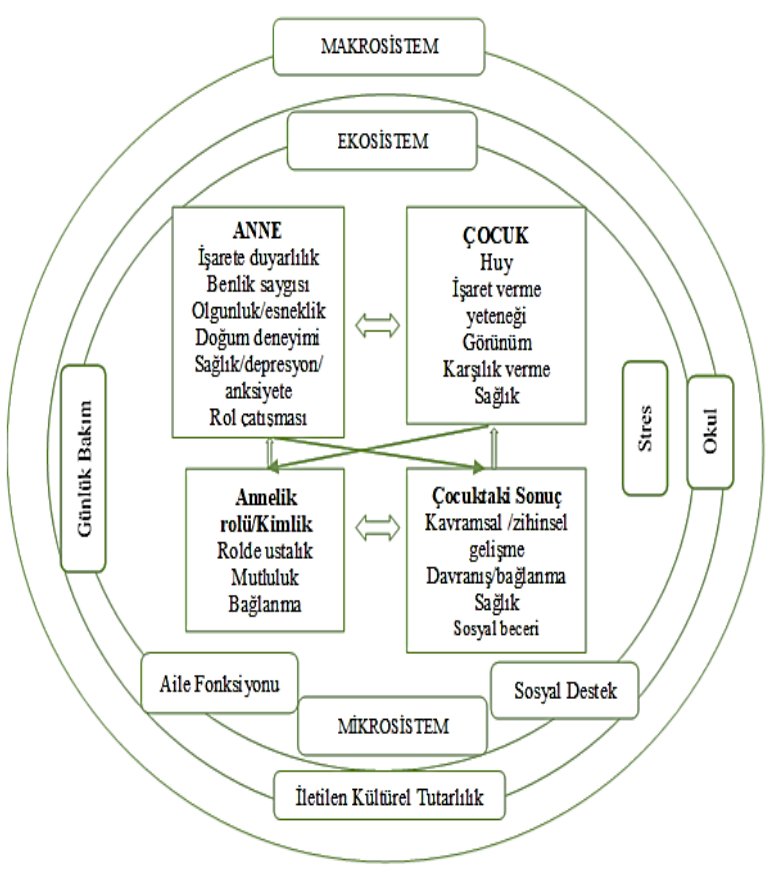

Şekil 3. Anne Rolü Kazanma Yeteneği Modeli ${ }^{8-9}$

Annenin bebeğe uyum sağlaması ve annelik davranışlarını geliştirmesi annelik rolünün kazanılması olarak tanımlanır. Annelik rolünü edinebilmek gebelikten önce gelişmeye başlar ve bebek doğduktan bir y1l sonraya kadar devam eder. Rol kazanımı her annede farklı zamanlarda gerçekleşebilir. Mercer yaptığı araştırmalarda annelik rolünün ortalama dördüncü ayda oluştuğunu saptamıştır. $6,8,9$

\section{Anne Olma}

Mercer, temellerini danışmanı Rubin'in attığı annelik rolü kazanma yeteneği kuramını geliştirmekle kalmadı ayrıca anneliğin sadece rol kazanılarak biten bir süreç olmadığını düşündüğü için sonrasında anne olma kuramını geliştirdi. Çünkü rol edinme, annenin sürekli değişimi içermemekte ve bir son noktası bulunmaktadır. Mercer'a göre anne olmak sürekli değişen ve evrim geçiren bir süreçtir. ${ }^{10} \mathrm{Bu}$ nedenle Mercer, 2003 y1lında “Annelik Rolü Yeteneği Teorisi”ni yeniden ele almış ve değişiklikler önermiştir. Mercer, annelik Rolü yeteneği yerine "anne olmak" terimini kullanmayı tercih etmiştir. 6,8,9,18 $\mathrm{Bu}$ doğrultuda Mercer, anne olma kuramını oluşturmuştur. Ancak anne olma kuramında eleştirilen önemli bir zayıf nokta bulunmaktadır. Mercer anne olmanın hangi davranış sonucu kazanıldığını açıklamamıştır.

Anne olmanın aşamalarını ise annelik rolü yeteneğinin aşamaları ile paralel olarak yeniden isimlendirmiştir; ${ }^{19}$

1. Bağlılık, bağlanma ve hazırlık (gebelik dönemi boyunca)

2. Tanışma, uygulama ve fiziksel iyileşme (doğumdan sonraki ilk 2 hafta)

3. Yaklaşan normalleşme (doğumdan sonraki 2 hafta ile 4. ay arasi)

4. Annelik kimliğini elde etmek (doğumdan sonraki 4. ay ile 1yıl arası)

İlk aşamada annenin gebeliği kabulü, uyumu ve doğacak bebek için hazırlıkların yapılması ve bebeği ile bağlılığının oluşmaya başlaması yer alır. $\mathrm{Bu}$ aşama hamilelik sırasında başlar ve hamileliğe yönelik sosyal ve psikolojik düzenlemeleri içerir. Anne, karnındaki bebeğin hareketlerini hissetmesi ile bebeğini algılar ve bağlanma süreci başlar. $\mathrm{Bu}$ bağlılık zamanla artar ve annenin yetenekleri ile güçlenir. ${ }^{8-10}$

İkinci aşama bebeğin doğması ile başlar ve doğumdan sonraki ilk iki haftayı içerir. Bu aşamada anne bebeğini tanımaya çalışır, bakımını öğrenmeye gayret eder. Bu dönem bir kadının anne olma çalışmalarının başladığ dönemdir. Anne, rol modelinden veya profesyonellerden öğrendiği bakım davranışlarını yapmaya çalışır. Uygulama ile yetkinlik kazanır. Bu aşamada annenin aktif katılımı sürekli olarak anneliğe olumlu bir uyumla ilişkilendirilmiştir. ${ }^{8-10}$

Üçüncü aşamada ise anne, kendi annelik tarzını ortaya koymaya çalışır. Geçmiş deneyimlerine ve gelecekteki hedeflerine göre annelik stilini oluşturmaya başlar. Bu süreçte annede çok fazla bilişsel yapılanma meydana gelir. Anne, bebek ipuçlarını öğrenir ve kendi benzersiz annelik tarzını geliştirir. Mercer, bunu "yerleşmek" ve yeni bir aile olmak olarak tanımlamaktadır. ${ }^{8-10}$

Dördüncü aşama annelik kimliğini elde etme aşamasıdır. $\mathrm{Bu}$ aşama, kadının anneliği kendi sistemine entegre etmesi, rolü içselleştirmesi ve kendini yetkin bir anne olarak görmesi ile başlar. Anne kendi annelik stilini oluşturmuş, bu konuda ustalaşmış ve bebeği ile zaman geçirmenin tadını çıkarmaktadır. Anne, annelik faaliyetlerinde 
yetkin ve kendinden emin ve bebeği ile olan bağlılığını hissetmektedir. Bebek ise anne ile göz teması kurmakta, anneye gülümsemekte, temel güven duygusunu kazanmaktadır. ${ }^{10}$

Mercer, kuramında annelik rol yeteneği diyagramını kullanmamış bunun üzerinde de değişiklik yapmıştır. Ancak Bronfenbrenner'in etkileşen birbirinin içine geçmiş ekolojik sistemler kavramını kullanmaya devam etmiştir ve bu halkaların isimlerini yeniden adlandırmıştır. Mikrosistem yerine "aile ve arkadaş", ekosistem yerine "topluluk" ve makrosistem yerine de "toplum" kavramlarını kullamış ve diyagramını daha sade hale getirmiştir (Şekil 4). ${ }^{11}$

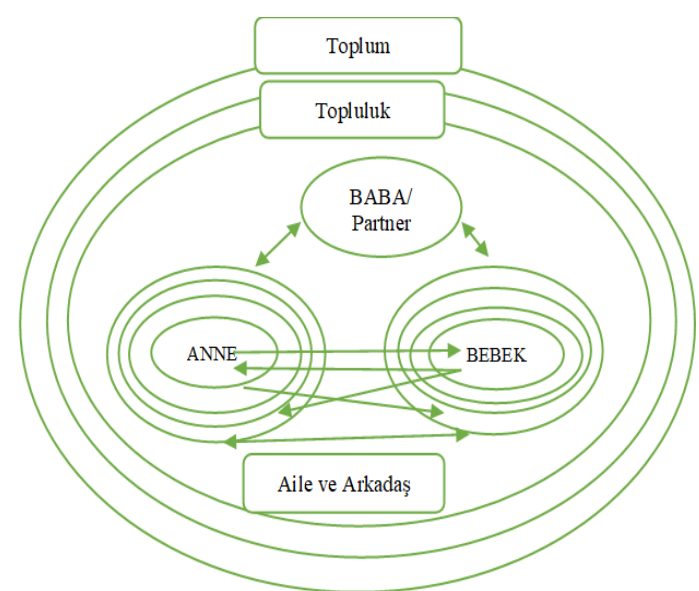

Şekil 4. Anne Olma Modeli ${ }^{11}$

Aile ve arkadaşlar; anne olmayı etkileyen en yakın sistemdir. Anne- baba- bebek arasındaki etkileşimi kapsar. $\mathrm{Bu}$ sistemde fiziksel ve toplumsal destek, aile değerleri, ebeveynlik için kültürel özellikler, bilgi beceri aile işlevi ve bağlılık yer almaktadır.

Topluluk; aile ve arkadaş katmanını saran sistemdir. Bu sistemde kreş, ibadethane, okul, iş ortamı, hastane, eğlence yerleri ve destek gruplar yer almaktadır.

Toplum; anne-baba-bebek etkileşimini saran en dış katmandır. İçinde yaşanılan kültürün, değerlerin, gelenek ve göreneklerin, toplum yapısının anne-baba-bebek ilişkisini ve anne olmayı etkilemesi yer alır. Kanun ve yasalarda bu sistem içinde yer almaktadır. ${ }^{10}$

\section{Mercer'e Göre Metaparadigma Tanımları İnsan}

Mercer'ın özel olarak bir insan kavramı tanımı yoktur. Ancak insan kavramı özellikle benlik saygısı ve benlik algısını içermektedir. Kadının annelik rolünü kazanabilmesi için öncelikle benlik saygısına sahip olması gerekir. Zira kendini kabul edemeyen kadin anne olmakta da güçlük yaşar. Kadının benlik algisı ne kadar olumlu ve benlik saygisı ne kadar yüksek ise annelik rol yeteneklerini de kazanması o kadar kolay olmaktadır., ${ }^{8,9}$

\section{Sağlık}

Mercer, sağlık kavramını; anne ve babanın geçmişteki sağlık durumları, mevcut sağlıkları, sağlıkla ilgili riskleri, hastalığa karşı dirençleri, duyarlılıkları ve kaygıları, hastalığa olan adaptasyonları ve hastalığın reddedilme algısı şeklinde ele almaktadır. ${ }^{6}$

\section{Çevre}

Mercer, Bronfenbrenner' in ekolojik sistem teorisinden ilham alarak çevreyi tanımlamıştır. Kişilerin içinde bulunduğu çevre hiyerarşik olarak (mikrosistemekosistem-makrosistem gibi) kişiyi etkilemekte ve kişiden etkilenmektedir. Özellikle çevreden gelen sosyal destek, stres gibi durumlar annelik rolünü, anne-baba iliş̧isini ve çocuk gelişsimini doğrudan etkilemektedir. ${ }^{6,8,10}$

\section{Hemşire}

Mercer'e göre hemşire; gebelik sırasında ve doğumdan sonra yani annelik sürecinin her aşamasında anne ile yoğun ve sürekli olarak etkileşim ve iletişimi sürdüren, anne, annenin yakın çevresi ve bebeğin sağlığ 1 için tespitte bulunan kişidir. Mercer'in kuramında hemşireler yardım eden kişilerdir ve bu yardım etmeyi gerçekleştirirken eğitici ve danışmanlık rollerini kullanırlar. Teoride hemşirelerin bakım verici rollerinin ele alınmaması ise teorinin eleştirilen bir diğer yönüdür. ${ }^{6,10}$

\section{Annelik Rolü Kazanımında Hemşirenin Sorumlulukları}

Bir bebeğin aileye katılması ile ailedeki tüm bireylerin rol ve sorumluluklarında birtakım değişmeler gerçekleşir. Her yeni bireyin katılması ile bu rol ve sorumluluklar 
yeniden şekillenir. Bireyler, bu yeni rol ve sorumlulukları yerine getirmeye çalışırken sorun yaşayabilmektedirler. Hemşirelerin bu noktada aileye yardımcı olma, danışmanlık gibi birçok rolleri bulunmaktadır. Öncelikli olarak hemşirenin rolü ebeveynleri bu durama hazırlamaktadır. $\mathrm{Bu}$ noktada desteğe ilk ihtiyacı olan kişi öncelikli olarak annedir. Özellikle kadının ilk doğumu ise ilk annelik deneyimi yaşayacaksa veya özel bir bebeğe sahip olacaksa ya da planlamadığı bir gebelik ise hiç kuşkusuz bu duruma yardım alarak hazırlanması gerekmektedir. Fakat sadece anne değil tüm aile hazırlanmalı ve tüm aileye destek olunmalıdır. Hemşireler doğum öncesinde gerekli destek, danışmanlık ve eğitimlerle aileyi hazırlamaya başlar ve doğum sonrasında da bu girişimler devam eder. ${ }^{8}$ Hemşireler yaptıkları destekle, aile ve bebek arasındaki ilişkinin güçlendirilmesini sağlar ve olası sorunları önlemek için riskleri belirler. Annenin gebelik veya annelik konusunda endişeleri ve soruları varsa hemşire çözüm bulmalı ve annenin sorularını yanıtlamalıdır. Annenin bebeğine karşı ön yargiları varsa bunu yenmesine, kendisini ve bebeğini olumlu algilamasına yardım etmelidir. Hemşire; anneye beslenme, banyo, tırnak bakımı, alt bakımı gibi temel bebek bakımını öğretmelidir. Anne-bebek bağının güçlenmesi için destekleyici girişimlerde bulunmalıdır. Kanguru bakımının önemi gibi çeşitli bakım uygulamalarını yaptırmalı ve öğretmelidir. Bebekte temel güven duygusunun sağlanması açısından bebeğin tutarlı bakım almasının önemini anlatmalıdır. ${ }^{8,9}$

\section{Annelik Rolü Yeteneği ve Anne Olma Kuramını Anlama: Vaka Örneği}

M.K., 17 yaşında ve 8 haftalık gebedir. Ortaokuldan sonra eğitim hayatına devam etmemiş ve erken yaşta ailesinin izni ile evlenmiştir. Eşi 19 yaşında O.K. Lise mezunudur ve alışveriş merkezinde yarı zamanlı çalışmaktadır. Gelirleri ancak ikisinin giderlerini karşılamaktadır. M.K. ve eşinin ailesi şehir merkezinde oturmaktadır ve M.K.'nın kendi ailesi de köyde yaşamaktadır.

M.K. ve eşi aile planlaması yöntemlerini bilmediklerinden evlendiklerinden bir ay sonrasinda istenmeyen bir gebelik meydana gelmiştir. Henüz evlilik hakkında bile fikirleri olmayan ve bu duruma alışamayan çift gebelik durumunu öğrendiklerinde ise oldukça anksiyete ve stres yaşamaya başlamışlardır. M.K.'nın bu durumunu gebelik için kontrole gittiğinde hemşiresi fark eder. Hemşire, M.K.'nın ayrıntılı öyküsünü almıştır ve 6 haftalık gebe olan M.K.'yi bu duruma hazırlamaya başlamıştır.

\section{Karar ve Hazırlık Evresi (Beklentiler Aşaması)}

(Gebelik Öncesi Dönem Hemşirelik Girişimleri)

- Hemşire, bu aşamada M.K.'yı gebelik durumunu kabullenmesine ve gebeliğe alışmasını sağlamaya çalıştı. Öncelikle M.K. ve eşi O.K.'nın benlik algısı, benlik saygısı üzerinde durdu. Henüz evliliğe alışmamış olan çifte danışmanlık yaptı ve bu konuda bir uzmana yönlendirdi. Gebeliğe alışma sürecinde hemşire çiftin yanlarında oldu ve her ay birlikte toplanarak eksik yönlere çözüm aradılar. $\mathrm{Bu}$ süreçte hemşire benlik algılarını da yükseltmeye yardımcı olmak için gerekli girişimlerde bulundu.

- M.K. ve eşinin rol çatışmaları hemşire tarafından belirlendi. Eş ve ebeveynlik rolleri tanımlandı bu konuya ilişsin sorunlar tespit edildi. M.K. ve O.K. adölesan evlilik yaptıkları için henüz eş rollerine alışamamışken ebeveynlik rollerinin bu duruma eklenecek olması çift üzerinde anksiyete yaratmaktaydi. Hemşire ile her bir ayrı rol üzerinde konuşuldu bu rollerin birlikte nasıl yürütüleceği konusunda girişimler başlatıld 1 ve eş terapilerine de devam etmeleri gerektiği kararı alındı.

- Hemşire, M.K. ve eşinin anksiyete ve depresyona neden olan durumlarını saptadı. M.K. ve O.K.'nın özellikle bebek doğduktan sonra gelirlerinin yetmeyeceği konusunda ve bebek bakımına ilişskin kaygıları olduğunu belirledi. Hemşire gerekli ekonomik desteği almaları konusunda gerekli yönlendirmeleri yaptı ve bebek bakımı konusunda ise gerekli eğitimleri (besleme, giydirme, hijyen vb.) vermeye başladi.

- Hemşire bu evrede ailenin sosyal destek gruplarını saptand1. M.K.'ya bebek 
zamanda bebeğinin davranışlarını öğrenmeye,

bakımında eşinin annesinin yardım edeceği ve yarı zamanlı çalışan eşi O.K. da boş zamanlarında eşi M.K.'ya bebek bakımında destek olacağı belirlendi. Ayrıca hem M.K. hem de eşi için arkadaşlarıyla sürekli etkileşim içinde olmaları ve iletişimlerini kesmemeleri önerildi.

- $\quad \mathrm{Bu}$ evrede hemşirenin gerçekleştirdiği diğer bir girişim ise M.K. ve O.K.'nın sağlık durumlarını belirlemesidir. M.K. ve O.K.'nın herhangi bir sağlık sorununun mevcut olmadığını tespit etti.

$\mathrm{Bu}$ evre sonunda hemşire çiftin gebelik öncesi sorularına yanıtlar vermiş sorunlarına çözüm aramış, sosyal destek kaynaklarını belirlemiş, gerekli yönlendirmeleri yapmış, doğum öncesi eğitimlerini vermiştir. M.K. ve O.K. gebeliği kabullenip hazırlıklara başlamıştır.

M.K. sağlıklı bir şekilde 37 haftalık 2350 gr kız bebek dünyaya getirmiştir. Anne ve bebekte herhangi bir komplikasyon meydana gelmemiştir.

\section{Tanışma, Uygulama ve Fiziksel İyileşme (Formal Evre)}

(Doğumdan Sonraki İlk İki Hafta Hemşirelik Girişimleri)

- Hemşire M.K. ile bebeğinin temasını doğum sonraki ilk yarım saat içerinde gerçekleştirerek (kanguru bakımı) anne bebek bağlanması için önemli bir adım attı. Bu gerçekten M.K.'ye iyi geldi ve iyi hissettiğini belirtti. İlk emzirme deneyimini de hemşire ile birlikte gerçekleştirdi. Doğru emzirme tekniği ve pozisyonlarını öğrenmeye başladı.

- M.K.' nin taburculuğunda hemşiresi tekrar gerekli eğitimleri verdi hatırlatmaları yaptı (emzirme, banyo, giydirme vb.)

- Taburculuktan sonra hemşire ev ziyaretinde bulundu. M.K.'nin uyumu başarılı görünüyordu.

- Emzirme teknikleri doğruydu ve bebeğini besleyebiliyordu. Bebeğin ilk banyosu hemşire ve kayın validesi ile birlikte yapild1.

- M.K. hemşiresinden öğrendiği bakım davranışlarını yapmaya çalışıyor aynı bebeğinin verdiği ipuçlarını da anlamaya çalışıyordu.

- M.K.'nın algıladığ oldukça iyiydi. Eşi de sık sık bebek bakımında yardımc1 oluyordu. Eşi O.K. da kanguru bakımını oldukça sık yapıyordu.

\section{Yaklaşan Normalleşme (İnformal Evre)}

(Doğumdan Sonraki 2 Hafta ile 4 Hafta Aras1 Hemşirelik Girişimleri)

- Hemşire tarafından ev ziyaretleri ve evliliğe uyum için de M.K. ve eşinin terapileri devam ediyordu.

- M.K.'nın hem annelik hem eş rolü oldukça sağlıklı bir şekilde ilerliyordu ve rol çatışmaları yaşanmıyor denecek kadar azdı. Hem M.K. hem de eşi O.K. oldukça azimli görünüyordu. Arkadaşları ile de görüşmeyi ihmal etmiyorlardi.

- M.K. bebeğinin ipuçlarını öğrenmiş ve bakımında kendi annelik stillerini göstermeye başlamıştı.

- Bebekleri ise anne ile göz temasi kuruyor, refleksleri normal, annesine gülümsüyor ve tutarlı bir bakım aldığ 1 fark ediliyordu.

\section{Annelik Kimliğini Elde Etme (Kişisel Evre)}

(Doğumdan Sonra Yaklaşık 4. Ay ve 1 Yıl Arası Hemşirelik Girişimleri)

- M.K. ve eşi artık hem eş olmanın hem de ebeveyn olmanın tadını çıarıyordu. Rahatlamışlar kendilerine olan güvenlerini tam olarak kazanmışlardı.

- M.K. kendi annelik stilini tamamiyla oturtmuş ve esneklik sağlamaya başlamıştı. Bakımdaki ince ayrıntıları da görebiliyordu. Kendini artık yetkin bir anne olarak hissediyordu. $\mathrm{Bu}$ süreç ise yani annelik rol yeteneği kazanımı M.K. için doğumdan sonraki yedinci ayda kazanıldı.

- M.K. bebeği ile zaman geçirmekten zevk alıyordu ve bebeği ile olan bağlılığını hissettiriyordu. Bebek ise gayet sağliklı ve mutlu görünüyordu. Büyüme ve gelişmesi de normaldi. 


\section{SONUÇ VE ÖNERILLR}

Mercer, hocası Rubin'in annelik rolüne ulaşma teorisini geliștirmiş ve hocasının doğum sonrası bir ay incelediği annelik rolünü bir yıla kadar incelenmiştir. Yaptığı araştırmalarda ise ortalama dördüncü ayda annelik rolünün kazanıldığını belirlemiştir. Ayrıca Mercer, yalnızca sağlıklı anneler ile değil, özellikle komplikasyonlu gebelik yaşayan, engelli bebeğe sahip olan ya da adölesan anneler ile çalışmıştır. Yapılan bu çalıșmada planlanmamış gebeliği olan adölesan anne örneği ele alınmıștır. Vaka incelemesi sonucunda kuramın babayı da içermesi ve babanın önemini vurgulaması, hemşirelik girişimlerinde babanın da ele alınması, tüm aile ile birlikte hemşirenin de iş birliği içerisinde olması, hemşirenin anneyi doğum öncesinden başlayarak takip etmesi ve annelik rolünü kazanana kadar hemşirenin anneye destek olması kuramın güçlü yönlerini olușturduğu belirlenmiștir. Ancak bu sürenin çok uzun olması izlem ve takibi zorlaştırdığ 1 için uzun süre gözlem ve zaman gerektirmektedir. Ayrıca Mercer'in anne olma teorisinde en zayıf nokta, anne olmanın tam olarak ne zaman kazanıldığının yani hangi davranış sonrası anne olunduğunun açıklanmamasıdır. $\mathrm{Bu}$ nokta anne olma kuramında belirsiz kalmıştır ve en çok eleștirilen yön olmuștur. $\mathrm{Bu}$ nedenle anne olma kuramı tek başına kullanılmamakta ve annelik rolü yeteneği kuramı ile entegre olarak kullanılmaktadır.

Sonuç olarak annelik rolü yeteneği- anne olma kuramı planlanmamış gebeliklerde aileyi gebeliğge hazırlama, adölesan annelerde gebeliği yönetme, engelli çocuğu olan ailelere gerekli desteği vermede, komplikasyonlu gebeliklerde sorunları çözümlemede hemşirelere yol gösterici olmaktadır. Ayrıca gebeliğe karşı ön yargıları yıkmada, anneye bebek bakımı öğretmede, annenin yeterlilik kazanmasında, babanın desteğinin alınmasında, anne-bebek, baba bebek bağlanmasında kullanması gereken önemli bir kuramdir. Tüm bu gruplar hemşirelerin önemli ve zorlu çalışma alanlarını oluşturmaktadır. $\mathrm{Bu}$ kuram hemşirelere bu gruplarla çalışırken nasıl bir yol izlemeleri gerektiğini bilimsel olarak sunmaktadır. $\mathrm{Bu}$ doğrultuda hemşirelerin belirtilen tüm bu gruplarla çalışırken yaptıkları girişimleri bilimsel bilgiye dayandırmaları, hemşirelik kuramlarımızı bir diğer deyișle mesleğimize özgü hemşirelik literatürümüzü kullanmak, uygulamalara yansitmak ve pratik girişimlere entegre etme açisından bu kuramı kullanmaları önerilmektedir

KAYNAKLAR

1. http://www.hips.hacettepe.edu.tr/tnsa2018/rapor/TNSA2018_an a_Rapor.pdf. [Erişim tarihi: 20.07.2020].

2. Çınar, N, Alvur, T.M, Menekşe, D, Sevimli Güler, D. (2019) "First Breastfeeding Experience of Adolescent Mothers: A Qualitative Study.” Arc Health Sci Res, 6, 329-341.

3. Malabarey, OT, Balayla, J, Klam, SL, Shrim, A, Abenhaim, HA. (2012). "Pregnancies in Young Adolescent Mothers a Population-Based Study on 37 Million Births.” J Pediatr Adolesc Gynecol. 25, 98-102.

4. Çinar, N, Menekşe D. (2017). "Affects of Adolescent Pregnancy on Health of Baby.” Open J Pediatr Neonatal Care, 2(1), 12-23.

5. https://prabook.com/web/ramona_thieme.mercer/88171 [Erişim tarihi: 10.05.2020]

6. Oçakçı, A. F, Ecevit Alpar, Ş. (2013). Hemşirelikte Kavram, Kuram ve Model Örnekleri. 1. Baskı. İstanbul: İstanbul T1p Kitapevi.

7. https://en.wikipedia.org/wiki/Ramona T. Mercer. [Erişim tarihi: 8.04.2020].

8. Özkan, H. (2010). Annelik Kimlik Gelişimi Eğitiminin Primiparların Annelik Rolü Kazanımına ve Bebeğim Algısına Etkisi. Sağlık Bilimleri Enstitüsü, Doktora Tezi, Erzurum Atatürk Üniversitesi.
9. Taner, S. (2014). Planlanmamıs Gebeliklerin Doğum Sonrası Erken Dönemdeki Annelik Davranışına Etkisi. Sağlık Bilimleri Enstitüsü, Yüksek Lisans Tezi, Aydın Adnan Menderes Üniversitesi.

10. Mercer, R.T. (2004). "Becoming a Mother Versus Maternal Role Attainment." Journal of Nursing Scholarship, 36 (3), 226-232.

11. https://nursekey.com/mercers-becoming-a-mother-theory-innursing-practice/. [Erişim tarihi: 5.3.2020].

12. Copeland, D.B, Harbaugh, B.L. (2004). "Transition of Maternal Competency of Married and Single Mothers in Early Parenthood". The Journal of Perinatal Education, 13 (4), 3-9.

13. Eslek, D, Yilmaz Irmak, T. (2018). "Ekolojik Sistemler Kuramı Çerçevesinde Göçmen Çocuklar ve Oyunları Üzerine Bir Derleme." Dokuz Eylül Üniversitesi Sosyal Bilimler Enstitüsü Dergisi, 20 (3), 347-362.

14. Bronfenbrenner, U, Ceci, S.J. (1994). "Nature-Nuture Reconceptualized in Developmental Perspective: A Bioecological Model.” Psychological Review, 101(4), 568-586.

15. Doğan, A. (2010). "Ekolojik Sistemler Kurami Çerçevesinde Akran Zorbalığının İncelenmesi.” Çocuk ve Gençlik Ruh Sağlığı Dergisi, 17 (3), 149-162. 
16. Bronfenbrenner, Evans. (2000). "Developmental Science in the 21st Century: Emerging Questions, Theoretical Models, Research Designs and Empirical Findings." Social Development, 9 (1),115-125.

17. https://tr.wikipedia.org/wiki/Ekolojik_sistemler_teorisi. [Erişim tarihi: 6.3.2020]

18. Evcili, F, Bekâr, M, Yurtsal, B, Abak G, Tali, B, Temel, S. (2017). "Doğum Sonu Dönemdeki Kadınların Annelik Rolüne Hazıroluşluk Durumlarının ve Özgüvenlerinin Değerlendirilmesi." STED, 27 (1), 56-61.

19. Boz, İ, Özçetin, E, Teskereci, G. (2018). "İnfertilitede Anne Olma: Kuramsal Bir Analiz.” Psikiyatride Güncel Yaklaşımlar, 10(4), 506-521.

20. Mercer, R. (1986). First-time motherhood: Experiences from teens to forties. New York: Springer.

21. İrak, E.E. (2017). Travma Yaşamış Annelerin Tutumlarının Cocuklarının Gelisimine Etkisi Üzerinde Nitel Bir Arastırma. Sosyal Bilimler Enstitüsü, Yüksek Lisans Tezi, İstanbul: İstanbul Ticaret Üniversitesi.
22. Mercer, R. A (1981). "Theoretical Framework for Studying Factors That İmpact on The Maternal Role.” Nursing Research, 30 (2), 73-77.

23. Mercer, R. (1995). Becoming a Mother: Research on Maternal İdentity From Rubin To The Present. New York: Springer.

24. Beydağ, K.D. (2007). "Doğum Sonu Dönemde Anneliğe Uyum ve Hemşirenin Rolü.” TSK Koruyucu Hekimlik Bülteni, 6 (6), 479-484.

25. Mucuk, Ö, Özkan, H. (2018). "Doğum Sonrası Annelerin Doğum Memnuniyeti ve Annelik Rol Kazanımında Ebenin Rolü." Uluslararası Hakemli Kadın Hastalıkları ve Anne Çocuk Sağlığı Dergisi 12, 169-185.

26. Uçar, H. (2014). "Gebelerin Psikososyal Sağlık Durumları ile Annelik Rolü Arasındaki İlișki.” Sağlık Bilimleri Enstitüsü, Yüksek Lisans Tezi, Erzurum Atatürk Üniversitesi. 